\title{
Optimization of drying parameters for mango seed kernels using central composite design
}

\author{
Franck Junior Anta Akouan Ekorong ${ }^{1}$, Gaston Zomegni ${ }^{2}$, Steve Carly Zangué Desobgo ${ }^{3^{*}}$ and Robert Ndjouenkeu ${ }^{4}$
}

\begin{abstract}
Background: The combined effect of drying temperature and time was evaluated on residual water content, yield of oil extraction, total phenolic compounds and antioxidant activity of seed kernel from a Cameroonian local variety of mango (Local Ngaoundere). Response surface methodology (RSM) using central composite design (CCD) as tool, was used to develop, validate and optimize statistical models in order to establish the impact of the drying parameters (temperature and time) either alone or in combination.

Results: It was shown that drying temperature individually in its first order $\left(X_{1}\right)$ contributed 30.81, 21.11, 41.28 and 33.24\% while drying time individually in its first order $\left(X_{2}\right)$ contributed 39.91, 15.12, 29.92 and $25.87 \%$ for residual water content, yield of oil extraction, total phenolic components and antioxidant activity respectively. The increase of drying temperature increased antioxidant activity while the other physicochemical characteristics such as water content, yield of oil extraction and total phenolic components decreased. Concerning drying time, only water content was reduced with an increase of that factor. The synergetic effect of drying temperature and time was effective only for antioxidant activity. A compromise for optimization were then fixed for water content $\leq 10 \% \mathrm{w} / \mathrm{w}$; oil content $\geq 9 \% \mathrm{w} / \mathrm{w}$; total polyphenols $\geq 1 \mathrm{mg} / \mathrm{g}$ and antioxidant activity $\geq 1000 \mathrm{mg} \mathrm{AAE} / 100 \mathrm{~g} \mathrm{DM}$. A simulation for optimization gave, for $60 \mathrm{H}$ and $60^{\circ} \mathrm{C}$ for drying time and temperature respectively permitted to obtain $4.10 \% \mathrm{w} / \mathrm{w}, 9.53 \% \mathrm{w} / \mathrm{w}, 1340.28 \mathrm{mg} \mathrm{AAE} / 100 \mathrm{~g} \mathrm{DM}$ and $1.16 \mathrm{mg} / \mathrm{g}$ for water content, oil content, antioxidant activity and total polyphenols respectively.
\end{abstract}

Conclusions: The physicochemical characteristics studied was globally influenced by the chosen factors (drying time and temperature).

Keywords: Mango seed kernels; Drying; CCD; RSM; Modelling; Optimization

\section{Background}

Consumption and industrial exploitation of mango generate significant waste, mainly made of the peels and the seed kernel of the fruit, which account for $7 \%$ to $22 \%$ of the weight of the whole fruit [1]. In Cameroon, a rapid estimation of this waste based on the national mango production, evaluated to $539,000 \mathrm{t}$ in 2012 [2], showed that nearly 38,500 to $121,000 \mathrm{t}$ of mango waste are produced. Environmental, hygienic, and public health problems result in unorganized management of this waste $[3,4]$. Valorization of mango seed kernels through production of butter and biofunctional flour are the

\footnotetext{
* Correspondence: desobgo.zangue@gmail.com

${ }^{3}$ Department of Food Processing and Quality Control, University Institute of Technology (UIT) of The University of Ngaoundere, P.O. Box 455,

Ngaoundere, Cameroon

Full list of author information is available at the end of the article
}

main solutions technologically proposed, since different studies have shown that mango seed kernels contain various phenolic compounds. Mango seed kernel butter is used in cosmetics for its non-saponifiable matter content and its antioxidant activity potential [5-7]. The mango seed kernel flour displays interesting antioxidant and antibacterial properties [8-13]. These properties have also been found in mango peels [3]. Valorizing this biowaste as a potential source of non-conventional oil and natural antioxidants represents an opportunity to improve mango producer's income, particularly in regions where poverty is current. In this respect, drying of the seed kernels is one of the main technological steps both for efficient extraction of the functional components and for inactivation of enzymatic degradation of the raw material. Drying of mango seed kernels before extraction contributes then to stabilize the product and to increase the yield of extraction. 
Since the temperature and the time of drying may affect the activity and the stability of bioactive compounds, due to chemical and enzymatic degradation, low evaporation, and/or thermal degradation, a badly carried out drying can lead to physicochemical reactions which can lead to losses of the textural and nutritional values [14] and thus bring damage in the quality of the product. Optimizing the drying of seed kernels would then enable to make sure that the product obtained has desired quality.

The present paper aims at determining the optimal drying parameters (temperature and time) for mango seed kernels in order to improve the butter extraction with preservation of its total phenolic compounds and antioxidant capacity. Response surface methodology is used in this respect, the optimization procedure consisting in determining the drying temperature and time which minimize moisture and maximize total polyphenol content, oil content, and antioxidant activity.

\section{Methods \\ Material \\ Biological material}

Mango (Local Ngaoundere) was collected from a farm in Ngaoundere (Adamawa region, Cameroon) at harvest stage maturity acceptable by consumers.

\section{Chemicals}

Acetone, $\mathrm{n}$-hexane, tannic acid, methanol, trichloroacetic acid, and ascorbic acid were obtained from Sigma-Aldrich
Chemie GmbH, Munich, Germany. Sodium carbonate and phosphate buffer solution was obtained from SERVA Electrophoresis $\mathrm{GmbH}$, Germany. Folin-Ciocalteu, potassium hexacyanoferrate, and ferric chloride were from Fisher Scientific UK Ltd., Bishop Meadow Road, Loughborough, UK.

\section{Sample preparation}

The mango flesh was removed, the seed sundried, and the seed kernels extracted manually using a stainless steel knife to open the shell. The seed kernels were then open in two cotyledons of about $9.7 \pm 2.4 \mathrm{~mm}$ thickness for drying.

\section{Drying process}

The drying process parameters considered for the study were drying temperature and drying time. Preliminary tests were allowed to fix the limits of these factors. The seed kernel cotyledons were laid on a tray and dried using fixed temperatures and times according to the central composite design (CCD), in a tropical oven dryer [15]. The air velocity in the drying chamber was constant $\left(0.55 \mathrm{~ms}^{-1}\right)$, and the relative humidity of the chamber was $75 \pm 3 \%$ (Hanna Instruments HI 8564 Thermo hygrometer, Hanna Instruments, Woonsocket, RI, USA). The dried seed kernels were reduced in powder form with knife mills (Retsch GM 200 $\mathrm{GmbH}$, Retsch-Allee 1-542781 Haan, Germany) which are particularly suitable for grinding and homogenizing soft to medium-hard, elastic, fibrous, dry, or wet materials. It was assisted by a Retsch sieving shaker AS 300 permitted to obtain a particle size less than $1 \mathrm{~mm}$. That powder was preserved in a plastic bag at $4^{\circ} \mathrm{C}$ in darkness until use.

Table 1 Central composite design: coded variables, real variables, and responses

\begin{tabular}{|c|c|c|c|c|c|c|c|c|c|c|c|c|c|c|c|c|}
\hline \multirow[t]{3}{*}{ Number } & \multirow{2}{*}{\multicolumn{2}{|c|}{$\begin{array}{l}\text { Coded } \\
\text { variables }\end{array}$}} & \multirow{2}{*}{\multicolumn{2}{|c|}{$\begin{array}{l}\text { Real } \\
\text { variables }\end{array}$}} & \multicolumn{12}{|c|}{ Responses } \\
\hline & & & & & \multicolumn{3}{|c|}{ Moisture (\%) } & \multicolumn{3}{|c|}{ Oil content (\%) } & \multicolumn{3}{|c|}{$\begin{array}{l}\text { Total polyphenols } \\
\text { (\% DM) }\end{array}$} & \multicolumn{3}{|c|}{$\begin{array}{l}\text { Antioxidant activity } \\
\text { (eq } \mathrm{g} \text { of } \mathrm{VitC} / 100 \mathrm{~g} \mathrm{DM} \text { ) }\end{array}$} \\
\hline & $x_{1}$ & $x_{2}$ & $X_{1}$ & $X_{2}$ & Exp & Cal & Res & Exp & Cal & Res & Exp & Cal & Res & Exp & Cal & Res \\
\hline 1 & -1.00 & -1.00 & 44.85 & 13.64 & 16.59 & 17.86 & -1.27 & 9.14 & 9.05 & 0.09 & 0.99 & 1.11 & -0.12 & 477.12 & 581.02 & -103.90 \\
\hline 2 & 1.00 & -1.00 & 75.15 & 13.64 & 10.36 & 10.30 & 0.05 & 8.78 & 8.68 & 0.11 & 0.37 & 0.41 & -0.04 & 781.64 & 924.62 & -142.98 \\
\hline 3 & -1.00 & 1.00 & 44.85 & 61.36 & 7.72 & 8.11 & -0.39 & 9.16 & 9.32 & -0.16 & 1.30 & 1.30 & 0.00 & 892.26 & 723.22 & 169.04 \\
\hline 4 & 1.00 & 1.00 & 75.15 & 61.36 & 1.72 & 0.79 & 0.93 & 8.79 & 8.94 & -0.15 & 1.05 & 0.97 & 0.08 & $2,326.22$ & $2,196.42$ & 129.80 \\
\hline 5 & 0.00 & 0.00 & 60.00 & 37.50 & 4.80 & 5.79 & -0.99 & 9.45 & 9.56 & -0.11 & 0.86 & 0.94 & -0.08 & $1,144.65$ & $1,148.92$ & -4.27 \\
\hline 6 & 0.00 & 0.00 & 60.00 & 37.50 & 6.31 & 5.79 & 0.52 & 9.42 & 9.56 & -0.14 & 0.91 & 0.94 & -0.03 & $1,164.00$ & $1,148.92$ & 15.08 \\
\hline 7 & 0.00 & 0.00 & 60.00 & 37.50 & 4.91 & 5.79 & -0.88 & 9.49 & 9.56 & -0.07 & 0.81 & 0.94 & -0.13 & $1,150.18$ & $1,148.92$ & 1.26 \\
\hline 8 & -1.32 & 0.00 & 40.00 & 37.50 & 12.35 & 11.16 & 1.20 & 9.16 & 9.12 & 0.04 & 1.29 & 1.21 & 0.08 & 708.29 & 753.06256 & -44.78 \\
\hline 9 & 1.32 & 0.00 & 80.00 & 37.50 & 0.53 & 1.34 & -0.81 & 8.65 & 8.63 & 0.02 & 0.49 & 0.53 & -0.04 & $1,966.91$ & $1,952.15056$ & 14.76 \\
\hline 10 & 0.00 & -1.32 & 60.00 & 6.00 & 18.61 & 17.75 & 0.86 & 8.92 & 9.08 & -0.16 & 0.89 & 0.78 & 0.11 & 596.20 & 404.3872 & 191.81 \\
\hline 11 & 0.00 & 1.32 & 60.00 & 69.00 & 4.56 & 5.03 & -0.47 & 9.66 & 9.44 & 0.22 & 1.20 & 1.27 & -0.07 & $1,116.10$ & 1,337.6272 & -221.53 \\
\hline 12 & 0.00 & 0.00 & 60.00 & 37.50 & 4.77 & 5.79 & -1.02 & 9.39 & 9.56 & -0.16 & 1.07 & 0.94 & 0.13 & $1,145.52$ & $1,148.92$ & -3.40 \\
\hline 13 & 0.00 & 0.00 & 60.00 & 37.50 & 6.41 & 5.79 & 0.62 & 9.83 & 9.56 & 0.27 & 0.92 & 0.94 & -0.02 & $1,149.64$ & 1,148.92 & 0.72 \\
\hline 14 & 0.00 & 0.00 & 60.00 & 37.50 & 7.45 & 5.79 & 1.66 & 9.75 & 9.56 & 0.19 & 1.05 & 0.94 & 0.11 & $1,147.22$ & $1,148.92$ & -1.70 \\
\hline
\end{tabular}




\section{Experimental design, modelling, validation of the model, and optimization}

Response surface methodology (RSM) with CCD was used to carry out the experiments in order to model and optimize the following responses: residual water content, yield of oil extraction, total phenolic components, and antioxidant activity of the dried seed kernels. The independent variables (factors) were drying temperature $\left(x_{1}\right)$ and drying time $\left(x_{2}\right)$. The intervals of these factors were respectively $40^{\circ} \mathrm{C}$ to $80^{\circ} \mathrm{C}$ and 6 to $69 \mathrm{~h}$ (Table 1). The interval values of the factors were chosen considering the heat-sensitive effect of seed kernel components on oil [14] and polyphenols [16,17].

From the coded variables, many equations were used to transform them into real values to realize experiments in the laboratory. Those equations were as follows:

$$
\begin{aligned}
& X_{i}=X_{0 i}+x_{i} \times \Delta X_{i} \\
& N=k^{2}+2 k+k_{0}
\end{aligned}
$$

With the two factors, CCD had given a total of 14 experiments (with six replicates at the central point) as shown in Table 1 . The value of $\alpha$ was calculated in order to respect the orthogonality criterion [18] using the formula:

$$
\alpha=\left(\frac{2^{k}\left(\sqrt{2^{k}+2 k+n_{0}}+\sqrt{2^{k}}\right)^{2}}{4}\right)^{\frac{1}{4}}
$$

Mathematical models describing the relationships among the process-dependent variable and the independent variables in a second-order equation were developed [19]. Design-based experimental data were matched according to the following second-order polynomial equation:

$$
Y=\beta_{0}+\sum_{i=1}^{k} \beta_{i} x_{i}+\sum_{i=1}^{k} \beta_{i i} x_{i}^{2}+\sum \sum_{i<j}^{k} \beta_{i j} x_{i} x_{j}+\varepsilon
$$

where $Y$ is the response, $x_{i}$ and $x_{j}$ are the variables, $\beta_{0}$ is the constant, $\beta_{i}$ is the coefficient of the linear terms, $\beta_{i i}$ is the coefficient of the quadratic terms, and $\beta_{i j}$ is the coefficient of the interaction terms.

The coefficients of the models and statistical analysis (ANOVA) were obtained using the Minitab version 16 software (Minitab, Ltd., Brandon Court, Unit E1-E2 Progress Way, Coventry, CV3 2TE, UK), and the curves were plotted using Sigmaplot version 12.1 (Systat Software, Inc., 1735 Technology Drive, Suite 430, San Jose, CA 95110, USA).

Validating the models was obtained by calculating the absolute average deviation (AAD), the bias factor $\left(B_{\mathrm{f}}\right)$, and the accuracy factor $\left(A_{\mathrm{f}}\right)[20,21]$ which were expressed as follows:

$$
\begin{aligned}
& \mathrm{AAD}=\frac{\left[\sum_{i=1}^{N}\left(\frac{\left|Y_{i, \exp }-Y_{i, \mathrm{cal}}\right|}{Y_{i, \exp }}\right)\right]}{N}
\end{aligned}
$$

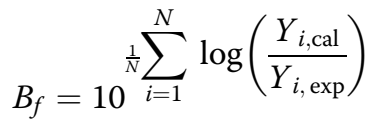

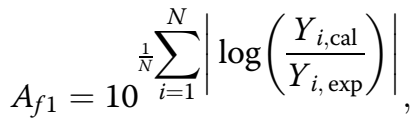

where $Y_{i, \text { exp }}$ and $Y_{i, \text { cal }}$ are respectively experimental and calculated responses and $N$ is the number of experiments used in the calculation.

Each linear, interaction, and quadratic contribution of each factor were obtained as follows:

For linear terms,

$$
\text { Contribution (\%) }=\frac{\left|\beta_{i}\right|}{\sum_{i=1}^{k}\left|\beta_{i}\right|+\sum_{i=1}^{k}\left|\beta_{i i}\right|+\sum \sum_{i<j}^{k}\left|\beta_{i j}\right|}
$$

For quadratic terms,

$$
\text { Contribution (\%) }=\frac{\left|\beta_{i i}\right|}{\sum_{i=1}^{k}\left|\beta_{i}\right|+\sum_{i=1}^{k}\left|\beta_{i i}\right|+\sum \sum_{i<j}^{k}\left|\beta_{i j}\right|}
$$

For interaction terms,

$$
\text { Contribution (\%) }=\frac{\left|\beta_{i j}\right|}{\sum_{i=1}^{k}\left|\beta_{i}\right|+\sum_{i=1}^{k}\left|\beta_{i i}\right|+\sum \sum_{i<j}^{k}\left|\beta_{i j}\right|}
$$

Lastly, optimization was done using the software Mathcad 15.0 (build 15.0.0.436 Parametric Technology Corporation, 140 Kendrick Street, Needham, MA 02494, USA). The conditions fixed were to minimize moisture and total polyphenols and maximize oil content and antioxidant activity. The use of Sigmaplot version 12.1 (Systat Software, Inc., 1735 Technology Drive, Suite 430, San Jose, CA 95110, USA) permitted to draw the contour plots and superimpose the graphs in order to determine the optimal zone.

\section{Analysis}

\section{Moisture content}

The determination of the moisture content was done using a standard method [22] and an isothermal oven (Heraeus, Type: T6, manufacturing no. 20001046, Kendro Laboratory Products, Langenselbold, Germany) for drying a known mass of the sample (using an electronic balance Gibertini no. 125186 , made in Milan, Italy) at $105^{\circ} \mathrm{C}$ for 
24 h. After cooling in a desiccator, the samples were reweighed (using an electronic balance Gibertini no. 125186, made in Milan, Italy). The water content (TE) representing the ratio of mass before and after heating in the oven is determined as a percentage.

\section{Lipid content}

The extraction of the lipid from seed kernels was made by the Soxhlet extraction method [23], using n-hexane as solvent. In practice, $600 \mathrm{~g}$ of dried mango seed kernel powder was used. The oil-hexane mixture obtained after extraction was separated on a rotary evaporator (Heidolph Salvis Electronic W 60) at $70^{\circ} \mathrm{C}$ to recover hexane. The oily extract, previously dried in an oven at $105^{\circ} \mathrm{C}$ for $20 \mathrm{~min}$ to evaporate residual $\mathrm{n}$-hexane solvent, was then weighed. The lipid content was determined in $\mathrm{g} / 100 \mathrm{~g}$ of dry matter (DM).

\section{Determination of total phenolic compound}

These analyses were based on the oxidation/reduction principle and employed Folin-Ciocalteu reagent [24]. Briefly, $0.5 \mathrm{~g}$ of each sample was weighed in a glass beaker, and $10 \mathrm{~mL}$ of $70 \%$ acetone was added. The whole was stirred for $20 \mathrm{~min}$ at room temperature $\left(25^{\circ} \mathrm{C}\right)$. The extract was centrifuged at $3,000 \mathrm{G}$ for $10 \mathrm{~min}$ at $4^{\circ} \mathrm{C}$. The supernatant was recovered and stored at $4^{\circ} \mathrm{C}$. Volumes of $0,10,20,30,40,50,60,70,80,90$, and $100 \mu \mathrm{L}$ of a tannic acid standard solution $(0.1 \mathrm{mg} / \mathrm{mL})$ for calibration curve and a suitable volume of extract were introduced into test tubes. The volumes were made up to $500 \mu \mathrm{L}$ with distilled water. To these solutions, $250 \mu \mathrm{L}$ of Folin-Ciocalteu reagent $(1 \mathrm{~N})$ and $1.25 \mathrm{~mL}$ of sodium carbonate (20\%) were added. The mixtures were agitated and incubated at room temperature in the dark. After $40 \mathrm{~min}$, the absorbance was read at $725 \mathrm{~nm}$ against the blank. The amount of total phenolic compound expressed by weight of tannic acid was then determined.

\section{The antioxidant activity}

To obtain the extract, $250 \mathrm{mg}$ of powder was mixed in $25 \mathrm{~mL}$ of methanol at room temperature $\left(25^{\circ} \mathrm{C}\right)$ for $2 \mathrm{~h}$ and centrifuged for $10 \mathrm{~min}$ at 4,000 G. The residue was extracted again with $25 \mathrm{~mL}$ of methanol and centrifuged $(4,000 \mathrm{G})$ for $2 \mathrm{~h}$ again. The mixture of the two volumes of extract was then evaporated using a rotary evaporator to reduce the sample to $25 \mathrm{~mL}$. This extract was recovered in sealed tubes and stored at $4^{\circ} \mathrm{C}$ until use. The antioxidant capacity of the different powder samples was assessed by determining their ability to reduce iron (III) to iron (II) [25].

In a test tube, $1 \mathrm{~mL}$ of each extract was mixed with $2.5 \mathrm{~mL}$ of a phosphate buffer solution (0.2 M, pH 6.6) and $2.5 \mathrm{~mL}$ of $1 \%$ potassium hexacyanoferrate $\left[\mathrm{K}_{3} \mathrm{Fe}\right.$ $\left.(\mathrm{CN})_{6}\right]$. The whole was incubated for $30 \mathrm{~min}$ at $50^{\circ} \mathrm{C}$ in a water bath. Then, $2.5 \mathrm{~mL}$ of $10 \%$ trichloroacetic acid was added and the mixture was centrifuged for $10 \mathrm{~min}$ using a Heraeus Biofuge Primor, Kendro Laboratory Products, Langenselbold, Germany. After that, $2.5 \mathrm{~mL}$ of the supernatant was taken and mixed with $2.5 \mathrm{~mL}$ of distilled water and $0.5 \mathrm{~mL}$ of an aqueous solution of $0.1 \%$ $\mathrm{FeCl}_{3}$. The absorbance was read at $700 \mathrm{~nm}$ using a spectrophotometer Rayleigh VIS-723N (Beijing Beifen-Ruili Analytical Instrument (Group) Co., Ltd., Beijing, China). A calibration curve was done using ascorbic acid as reference at different concentrations. The total reducing power was expressed as equivalent of ascorbic acid (AAE).

\section{Results and discussion}

\section{Mathematical modelling}

Modelling of the action of drying temperature and time on four key drying parameters, residual water content, yield of oil extraction, total phenolic components, and antioxidant activity was carried out by modelling the experimental design required for laboratory purposes (Table 1). The mathematical models obtained were as follows, respectively:

$$
\begin{aligned}
& Y_{\text {water }}\left(x_{1}, x_{2}\right)= 5.793-3.718 x_{1}-4.816 x_{2} \\
&+ 0.060 x_{1} x_{2}+0.261 x_{1}^{2} \\
&+ 3.212 x_{2}^{2} \\
& Y_{\text {oil }}\left(x_{1}, x_{2}\right)=9.558- 0.187 x_{1}+0.134 x_{2} \\
&-0.002 x_{1} x_{2}-0.391 x_{1}^{2}-0.172 x_{2}^{2} \\
& Y_{\text {polyphenols }}\left(x_{1}, x_{2}\right)= 0.939-0.258 x_{1}+0.187 x_{2} \\
&+0.092 x_{1} x_{2}-0.040 x_{1}^{2} \\
&+0.048 x_{2}^{2} \\
& 1,148.92+454.2 x_{1} \\
&+353.5 x_{2}+282.4 x_{1} x_{2} \\
&+116.9 x_{1}^{2}-159.5 x_{2}^{2}
\end{aligned}
$$

with $Y_{\text {water }}\left(x_{1}, x_{2}\right)$ representing the mathematical model for water content; $Y_{\text {oil }}\left(x_{1}, x_{2}\right)$, the mathematical model for oil content; $Y_{\text {polyphenols }}\left(x_{1}, x_{2}\right)$, the mathematical model for total polyphenols; $Y_{\text {antioxidant }}\left(x_{1}, x_{2}\right)$, the mathematical model for antioxidant activity; $x_{1}$, the drying temperature; and $x_{2}$, the drying time.

The mathematical models were polynomials and validated according to the method described by Ross [20] as shown in Table 2 . The factors of the models were of first

Table 2 Model validation data

\begin{tabular}{lllll}
\hline Models & $\boldsymbol{R}^{\mathbf{2}}$ & $\mathbf{A A D}$ & $\boldsymbol{B}_{\mathbf{f}}$ & $\boldsymbol{A}_{\mathbf{f}}$ \\
\hline$Y_{\text {water }}\left(X_{1}, X_{2}\right)$ & 0.966 & 0.246 & 1.023 & 1.245 \\
$Y_{\text {oil }}\left(X_{1}, X_{2}\right)$ & 0.824 & 0.014 & 1.000 & 1.015 \\
$Y_{\text {polyphenols }}\left(X_{1}, X_{2}\right)$ & 0.890 & 0.083 & 1.008 & 1.086 \\
$Y_{\text {antioxidant }}\left(X_{1}, X_{2}\right)$ & 0.948 & 0.090 & 0.996 & 1.097 \\
\hline
\end{tabular}


Table 3 Estimated coefficient impact and contributions to moisture, oil content, total polyphenols, and antioxidant activity

\begin{tabular}{|c|c|c|c|c|c|c|c|c|c|c|c|c|}
\hline \multirow[t]{2}{*}{ Source } & \multicolumn{3}{|l|}{ Moisture } & \multicolumn{3}{|l|}{ Oil content } & \multicolumn{3}{|c|}{ Total polyphenols } & \multicolumn{3}{|c|}{ Antioxidant activity } \\
\hline & Coefficients & $P$ & $\begin{array}{l}\text { Contribution } \\
\text { (\%) }\end{array}$ & Coefficients & $P$ & $\begin{array}{l}\text { Contribution } \\
\text { (\%) }\end{array}$ & Coefficients & $P$ & $\begin{array}{l}\text { Contribution } \\
\text { (\%) }\end{array}$ & Coefficients & $P$ & $\begin{array}{l}\text { Contribution } \\
\text { (\%) }\end{array}$ \\
\hline$A: x_{1}$ & -3.718 & 0.000 & 30.81 & -0.187 & 0.033 & 21.11 & -0.258 & 0.000 & 41.28 & 454.200 & 0.000 & 33.24 \\
\hline $\mathrm{B}: \mathrm{x}_{2}$ & -4.816 & 0.000 & 39.91 & 0.134 & 0.104 & 15.12 & 0.187 & 0.002 & 29.92 & 353.500 & 0.000 & 25.87 \\
\hline $\mathrm{AA}$ & 0.261 & 0.612 & 2.16 & -0.391 & 0.001 & 44.13 & -0.040 & 0.397 & 6.40 & 116.900 & 0.080 & 8.55 \\
\hline $\mathrm{BB}$ & 3.212 & 0.000 & 26.62 & -0.172 & 0.067 & 19.41 & 0.048 & 0.321 & 7.68 & -159.500 & 0.026 & 11.67 \\
\hline$A B$ & 0.060 & 0.924 & 0.50 & -0.002 & 0.986 & 0.23 & 0.092 & 0.137 & 14.72 & 282.400 & 0.004 & 20.67 \\
\hline
\end{tabular}

degree $\left(x_{1}\right.$ and $\left.x_{2}\right)$, of second degree $\left(x_{1}^{2}\right.$ and $\left.x_{2}^{2}\right)$, and of interaction $\left(x_{1} x_{2}\right)$ form. They were statistically significant or not if the probability $(P)$ was $\leq 0.05$ or $\geq 0.05$, respectively (Table 3).

\section{Effect of drying temperature}

The impact of drying temperature $\left(x_{1}\right)$ on physicochemical characteristics of Local Ngaoundere mango seed kernels was significant on the decrease of water content $(P=0.000)$, oil content $(P=0.033)$, and total polyphenols $(P=0.000)$, respectively (Table 3 ). Moreover, it had significant impact on the increase of antioxidant activity with $P=0.000$ (Table 3).

The effect of drying temperature on the moisture of mango seed kernels is shown in Figure 1a. Moisture decreased from $23.2 \% w / w$ (at $40^{\circ} \mathrm{C}$ ) with increasing drying temperature to attain a minimum level of $13.1 \% \mathrm{w} / \mathrm{w}$ at $80^{\circ} \mathrm{C}$. In this case, it could be linked to effective moisture diffusivity which increased with a decrease in moisture content. This may indicate that as the moisture content decreased, the permeability to vapor increased, and the pore structure remained open. The temperature of the seed kernels raised rapidly in the initial stages of drying, due to more absorption of heat during drying, as the seed kernels could have a high loss factor at higher moisture content. This increases the water vapor pressure inside the pores inducing the opening of seed kernel pores so that, in the first stage of drying, liquid diffusion of moisture could be the main mechanism of moisture transport. As drying progressed further, vapor diffusion could have been the dominant mode of moisture diffusion in the later part of drying as reported by the literature [26-30].

The effect of drying temperature on the oil content of mango seed kernels is shown in Figure 2. The oil content started from $8.64 \% w / w$ at $40^{\circ} \mathrm{C}$, then increased to $9.10 \% w / w$ at $56^{\circ} \mathrm{C}$ slightly (with a gap of $0.46 \% w / w$ obtained), and decreased significantly to $8.15 \% w / w$ at $80^{\circ} \mathrm{C}$ (with a gap of $0.95 \% w / w$ obtained) with a probability $P=0.033$ (Table 3). This could be explained by lipid autoxidation and photo- oxidation. In fact, due to the increase of drying temperature and oxygen, the oil oxidation autoxidation and photo-oxidation was promoted. This could have been virtually inevitable since mango seed kernel oil content polyunsaturated triglycerides could play a role in that oxidation [31]. Other factors that could affect oxidation included moisture content, presence of metals, enzyme activity, UV light, protein content, and other chemical reactions $[32,33]$.

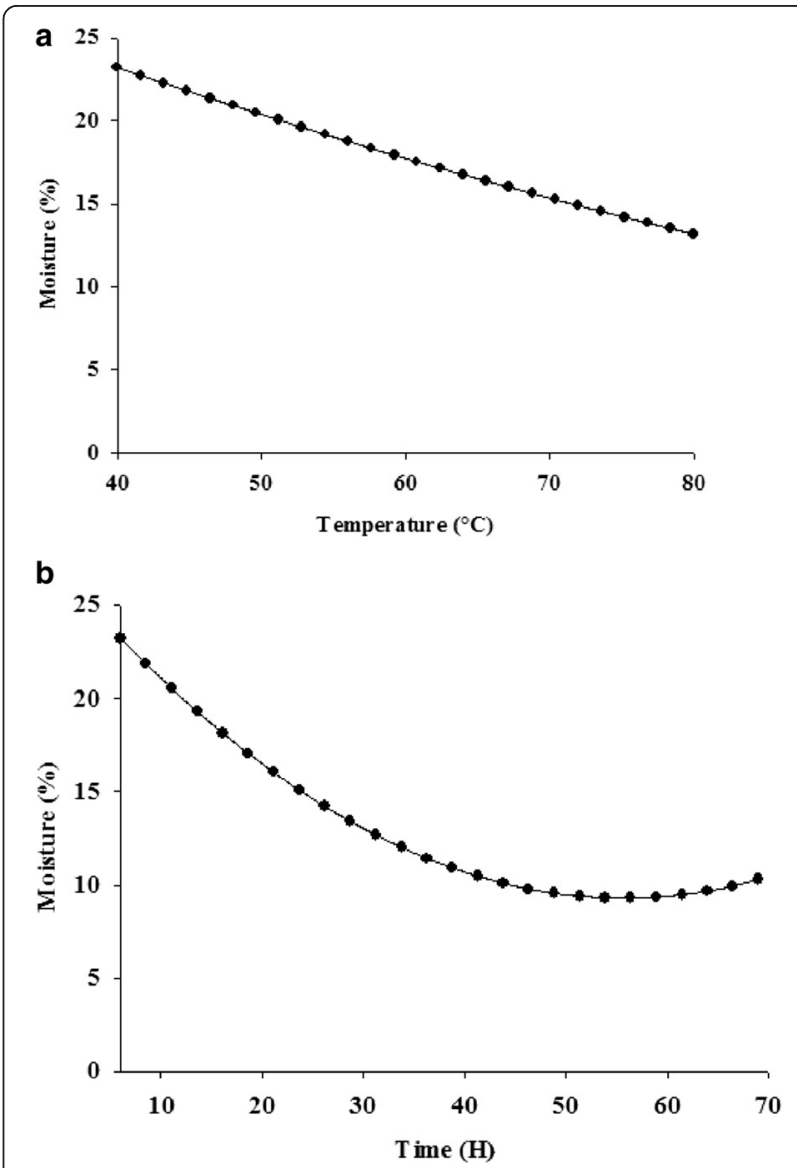

Figure 1 Effect of drying temperature and drying time on moisture. (a) Effect of drying temperature as the sole factor on the moisture of mango seed kernels (drying time fixed at 6 h). (b) Effect of drying time as the sole factor on the moisture of mango seed kernels (drying temperature fixed at $40^{\circ} \mathrm{C}$ ). 


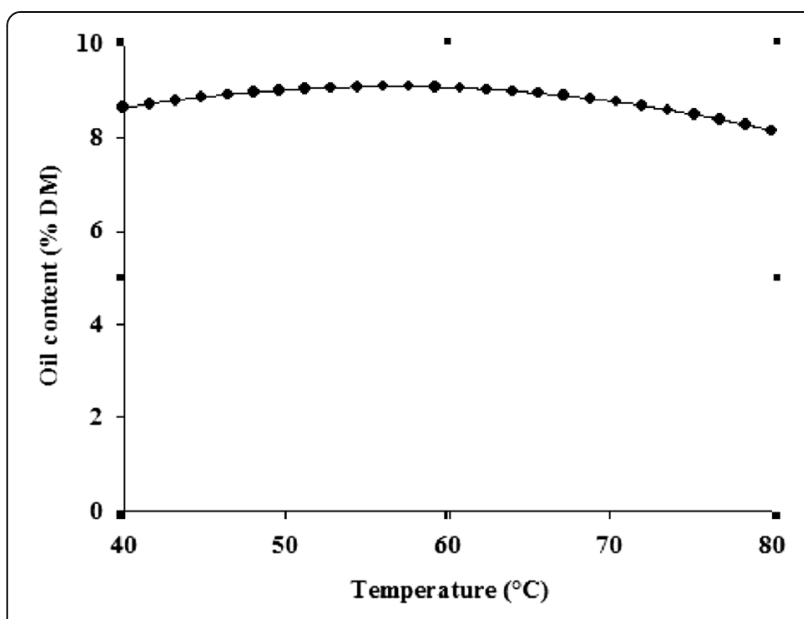

Figure 2 Effect of drying temperature on oil content. Effect of drying temperature as the sole factor on the oil content of mango seed kernels (drying time fixed at $6 \mathrm{~h}$ ).

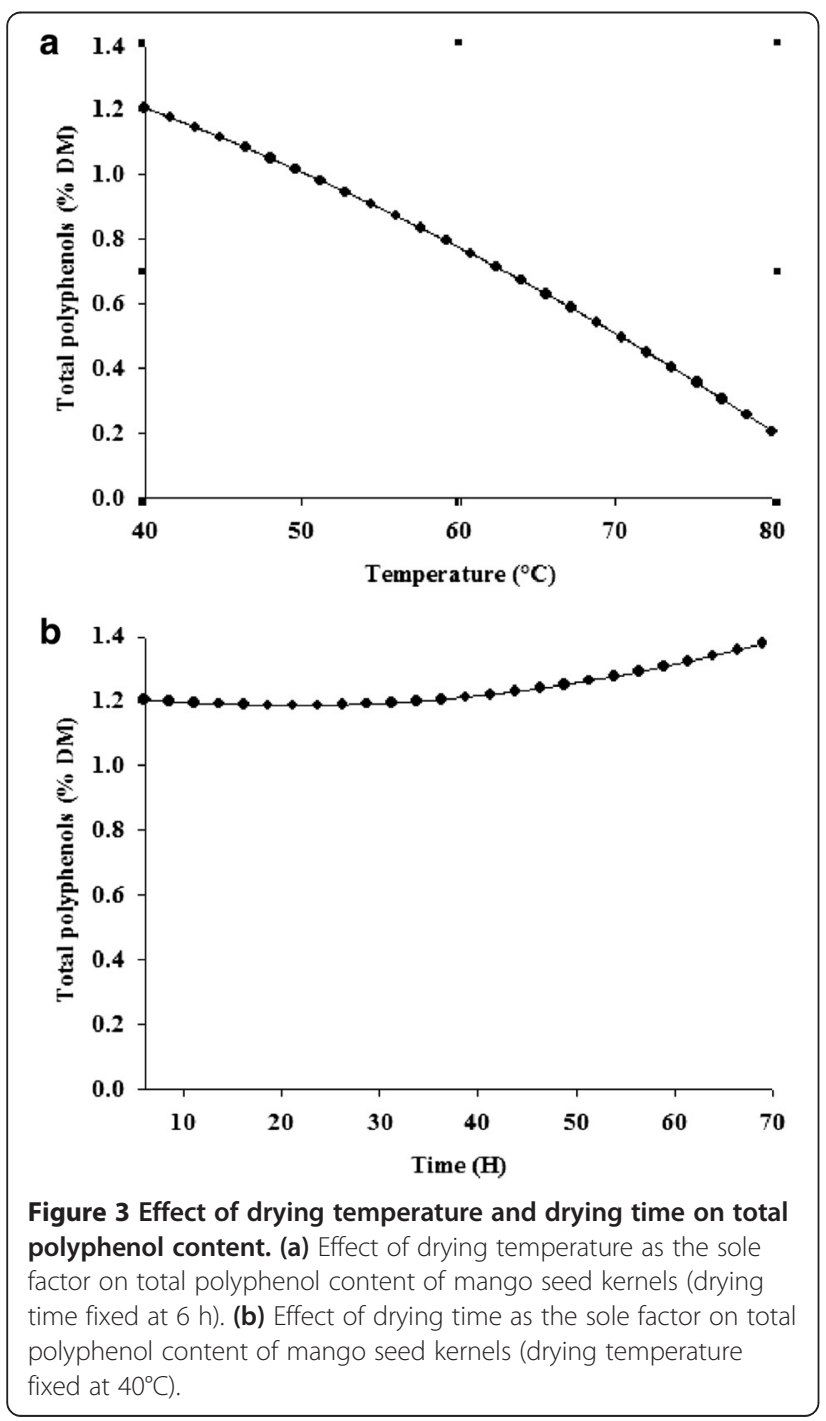

The effect of drying temperature on total polyphenols of mango seed kernels is shown in Figure 3a. Total polyphenols decreased from $1.20 \mathrm{mg} / \mathrm{g}\left(\right.$ at $\left.40^{\circ} \mathrm{C}\right)$ with increasing drying temperature to attain a minimum level of $0.20 \mathrm{mg} / \mathrm{g}$ at $80^{\circ} \mathrm{C}$. The reduced levels of the polyphenol compounds obtained from oven-dried mango seed kernels resulted from the degradation of phenolic compounds at high temperatures, due to chemical, enzymatic, or thermal decomposition [34].

The effect of drying temperature on antioxidant activity of mango seed kernels is shown in Figure 4a. The antioxidant activity started from $500.59 \mathrm{mg} \mathrm{AAE} / 100 \mathrm{~g}$ $\mathrm{DM}$ at $40^{\circ} \mathrm{C}$, then decreased to $390.21 \mathrm{mg} \mathrm{AAE} / 100 \mathrm{~g}$ $\mathrm{DM}$ at $54.72^{\circ} \mathrm{C}$ (with a gap of $110.38 \mathrm{mg} \mathrm{AAE} / 100 \mathrm{~g} \mathrm{DM}$ obtained), and increased significantly to $715.57 \mathrm{mg}$ $\mathrm{AAE} / 100 \mathrm{~g} \mathrm{DM}$ at $80^{\circ} \mathrm{C}$ (with a gap of $325.36 \mathrm{mg} \mathrm{AAE} /$ $100 \mathrm{~g}$ DM obtained) with a probability $P=0.000$ (Table 3 ). This could be explained by considering that high temperatures promote the inactivation of oxidative enzymes

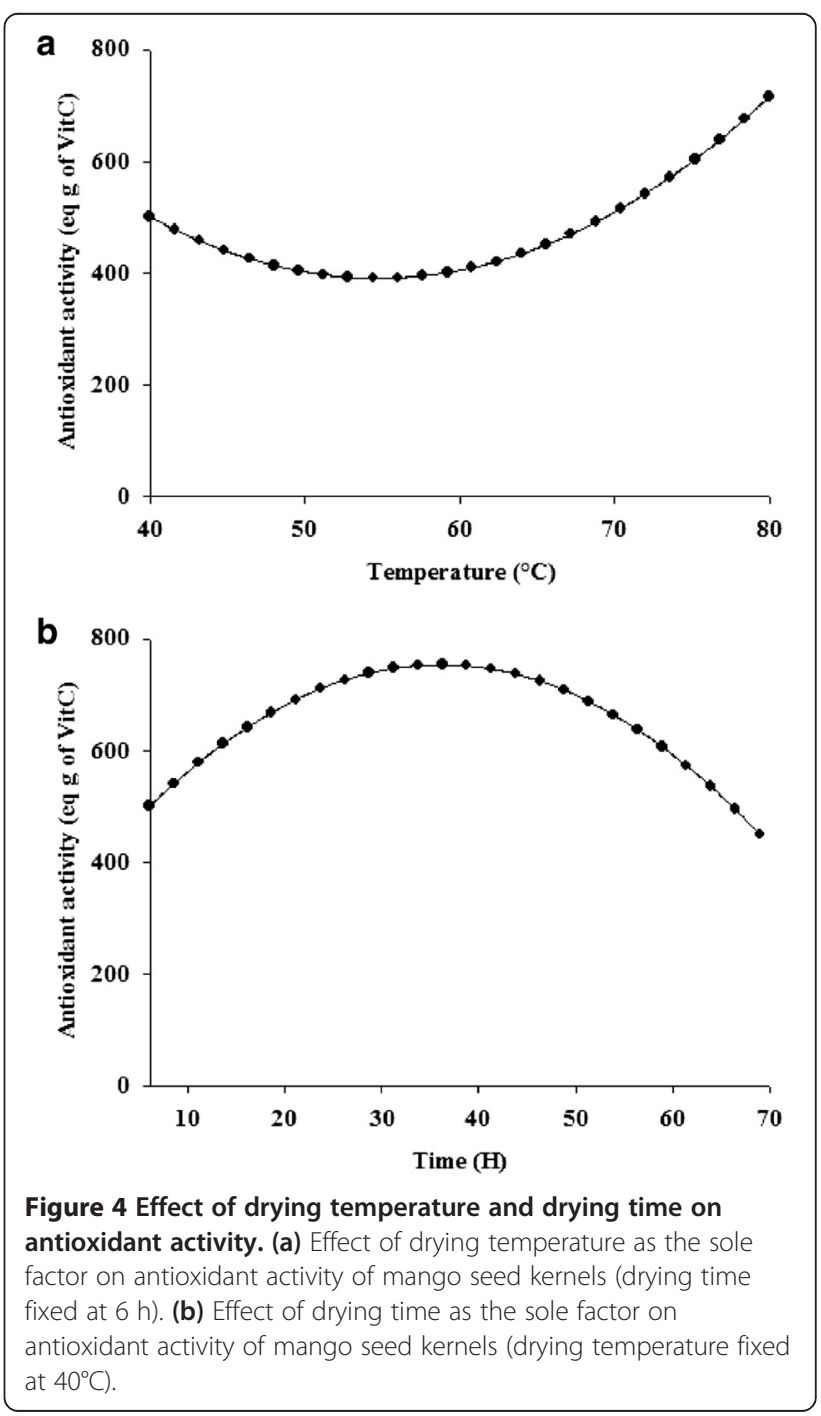


[35], avoiding the degradation of antioxidants. Furthermore, at high temperatures, the generation and accumulation of Maillard-derived melanoidins with a varying degree of antioxidant activity could also enhance the antioxidant properties of extracts [36].

\section{Effect of drying time}

The drying time $\left(x_{2}\right)$ as a sole factor on some physicochemical characteristics of Local Ngaoundere mango seed kernels had a significant impact on the decrease of water content $(P=0.000)$ and had a significant impact on the increase of total polyphenols $(P=0.002)$ and antioxidant activity $(P=0.000)$, respectively (Table 3$)$, while it had no significant impact on the increase or decrease of oil content with $P=0.104$ (Table 3).

The effect of drying time on the moisture of mango seed kernels is shown in Figure 1b. It started from 23.2\% $w / w$ at $6 \mathrm{~h}$ and then decreased to a minimum value of $9.3 \% w / w$ at $55.68 \mathrm{~h}$. After that, a slight increase until $10.3 \% w / w$ was observed at $69 \mathrm{~h}$. This could be explained by the fact that when air held the maximum possible amount of vapor, the vapor exerted a saturation vapor pressure, and since the water vapor present was less than the maximum, the air took up more moisture. This evaporation which took place from the surface of the seed kernels induced moisture decrease, and it could be attained using time [37].

Although phenolic compounds are considered as heat-sensitive compounds [38], the increase in the total polyphenols as the drying time lengthened was observed (Figure 3b). In fact, it started from $1.20 \mathrm{mg} / \mathrm{g}$ at $6 \mathrm{~h}$ and then increased to $1.38 \mathrm{mg} / \mathrm{g}$ at $69 \mathrm{~h}$. As far as this aspect is concerned, the literature shows contradictory results. But it could be explained by the sum of the content of the individual phenolic acids in the free fraction which significantly increased as the drying time lengthened as observed also for mandarin pomace [39].

The effect of drying time on antioxidant activity of mango seed kernels is shown in Figure 4b. It started from $500.58 \mathrm{mg} \mathrm{AAE} / 100 \mathrm{~g} \mathrm{DM}$ at $6 \mathrm{~h}$ and then increased to a maximum value of $753.64 \mathrm{mg} \mathrm{AAE} / 100 \mathrm{~g}$ $\mathrm{DM}$ at $36.05 \mathrm{~h}$. After that, it decreased until $449.71 \mathrm{mg}$ $\mathrm{AAE} / 100 \mathrm{~g} \mathrm{DM}$ at $69 \mathrm{~h}$. This result highlights the relationship between the previously observed enhancement of antioxidant potential and the increase in the content of some individual polyphenols. In fact, this could be explained by the fact that Maillard reaction products, which can be formed as a consequence of heat treatment or time, generally exhibit strong antioxidant properties [40-43].

\section{Effect of interaction drying temperature/drying time}

The impact of interaction of drying temperature/drying time $\left(x_{1} x_{2}\right)$ on some physicochemical characteristics of

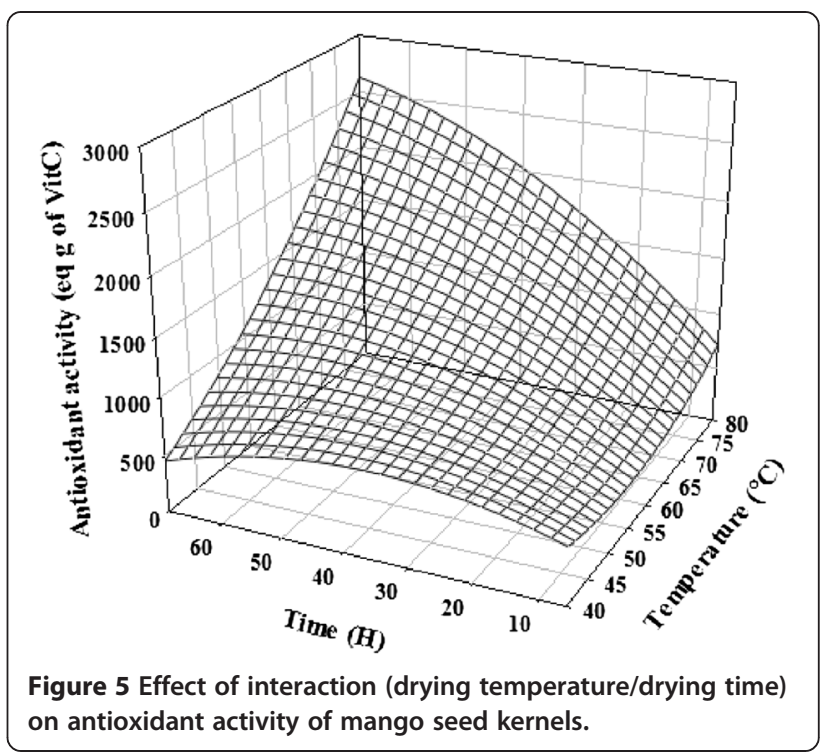

Local Ngaoundere mango seed kernels was not significant on water content $(P=0.924)$, oil content $(P=$ $0.986)$, and total polyphenols $(P=0.137)$ (Table 3$)$, while it was significant on the increase of antioxidant activity $(P=0.004)$ (Table 3$)$.

The effect of interaction of drying temperature/drying time $\left(x_{1} x_{2}\right)$ on the increase of antioxidant activity of mango seed kernels is shown in Figure 5. This could be explained as before by the fact that an increase of temperature and time results in more Maillard reaction products, permitting to exhibit strong antioxidant activities as mentioned in the literature [40-43].

\section{Optimization}

The results obtained for the action of drying parameters (time and temperature) on water content, fats content, total polyphenols, and antioxidant activity on the basis of the models were optimized to determine satisfactory domains of compromise. These domains were obtained for four key physicochemical characteristics of mango seed kernels, by fixing them at water content $\leq 10 \% w / w$ [44], oil content $\geq 9 \% w / w$, total polyphenols $\geq 1 \mathrm{mg} / \mathrm{g}$, and antioxidant activity $\geq 1,000$ mg AAE/100 g DM.

A drying parameter couple of $60 \mathrm{~h}$ and $60^{\circ} \mathrm{C}$ respectively for drying time and temperature permitted to obtain $4.10 \% w / w, 9.53 \% w / w, 1,340.28 \mathrm{mg} \mathrm{AAE} / 100 \mathrm{~g}$ $\mathrm{DM}$, and $1.16 \mathrm{mg} / \mathrm{g}$ respectively for water content, oil content, antioxidant activity, and total polyphenols. Also, a drying parameter of $60 \mathrm{~h}$ and $65^{\circ} \mathrm{C}$ respectively for drying time and temperature permitted to obtain $2.92 \%$ $w / w, 9.43 \% w / w, 1,590.49 \mathrm{mg} \mathrm{AAE} / 100 \mathrm{~g} \mathrm{DM}$, and 


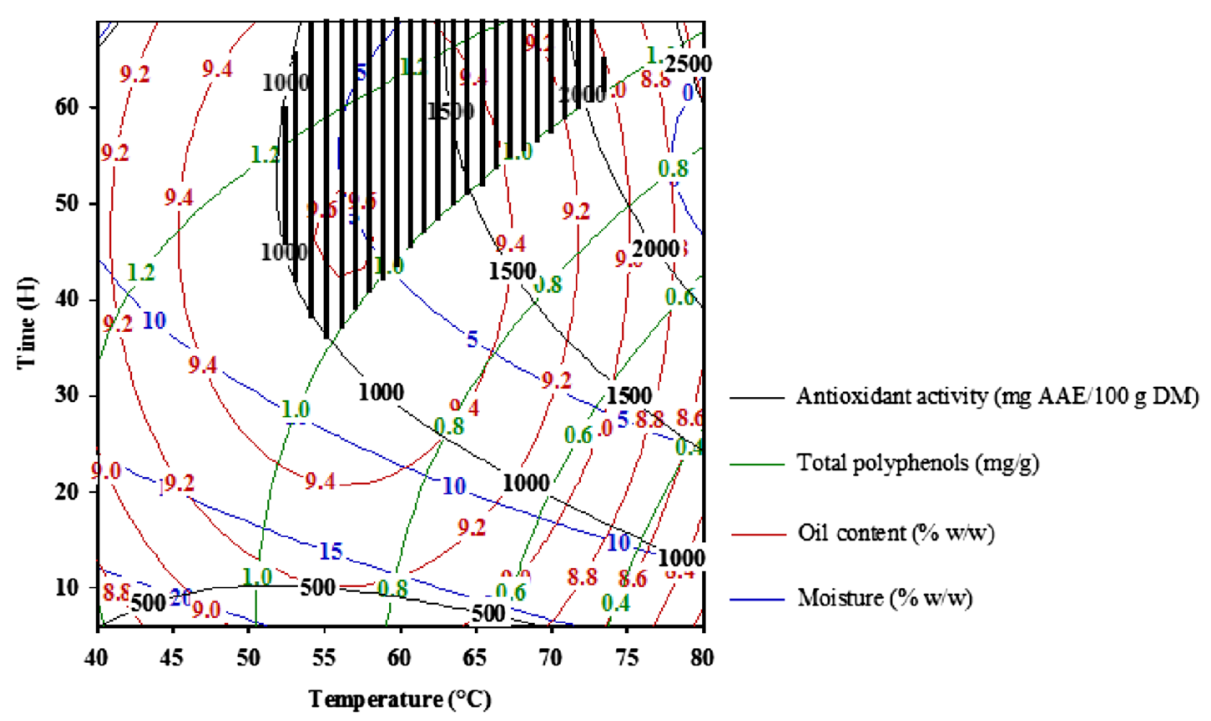

Figure 6 Response surface curves for drying temperature and time combinations. Response surface curves for drying temperature and time combinations providing for compromised physicochemical properties for mango seed kernels (Local Ngaoundere).

$1.10 \mathrm{mg} / \mathrm{g}$ respectively for water content, oil content, antioxidant activity, and total polyphenols. The results were thus confirming that the areas exploitable (Figure 6) for efficient drying respecting the conditions fixed before were valid.

\section{Conclusions}

The effects of drying parameters (drying temperature and time) on some physicochemical characteristics of mango seed kernels were studied. Drying temperature was impacting more than the drying time. The interaction was only significant for antioxidant activity, meaning that there was no synergetic action of drying temperature and time for water, oil, and total polyphenol content. The study showed that satisfactory properties could be achieved when acting on drying parameters. Optimization of physicochemical properties of mango seed kernels showed that compromise could permit to obtain physicochemical characteristics of importance in order to assess the exploitability of the results for the valorization of mango seed kernels.

\footnotetext{
Abbreviations

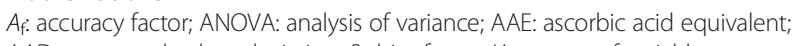
AAD: average absolute deviation; $B_{f}$. bias factor; $X_{0}$; center of variable; CCD: central composite design; $R^{2}$ : coefficient of determination; $\beta_{i j}$ : coefficient of the interactions terms; $\beta_{i}$ : coefficient of the linear terms; $\beta_{i j}$; coefficient of the quadratic terms; $x_{i}$ : coded variables given by the Doehlert table; $\beta_{0}$ : constant term; DM: dry matter; $Y_{i, \text { exp }}$ : experimental response; $\Delta X_{i}$ increment; $k_{0}$ : number of center points; $N$ : number of experiments; $k$ : number of variables;

$P$ : probability level; $X_{i}$. real variables; Res: residue; $Y$ : response; RSM: response surface methodology; $Y_{i, \text { cal }}$ : theoretical response.
}

\section{Competing interests}

The authors declare that they have no competing interests.

\section{Authors' contributions}

All authors have directly participated in the planning, execution, or analysis of this study. All authors of this paper have read and approved the final version submitted.

\section{Acknowledgements}

This work was undergone in the framework of the research group TQI2A (Technologie, Qualité et Innovations Agro Alimentaires) funded by AIRD (Agence Inter Etablissements de Recherche pour le Développement).

\section{Author details}

'Department of Process Engineering, National School of Agro-Industrial Sciences (ENSAI), University of Ngaoundere, P.O. Box 455, Ngaoundere, Cameroon. ${ }^{2}$ Department of Textile and Leather Engineering, The Higher Institute of the Sahel, University of Maroua (ISS), P.O. Box 46 Maroua, Cameroon. ${ }^{3}$ Department of Food Processing and Quality Control, University Institute of Technology (UIT) of The University of Ngaoundere, P.O. Box 455, Ngaoundere, Cameroon. ${ }^{4}$ Department of Food Science and Nutrition, National School of Agro-Industrial Sciences (ENSAI) of The University of Ngaoundere, P.O. Box 455, Ngaoundere, Cameroon.

Received: 10 September 2014 Accepted: 2 January 2015

Published online: 01 March 2015

\section{References}

1. Bafode BS (1988) Projet de transformation et de conditionnement des mangues à Boundiali en Côte d'Ivoire. SIARC (Section des ingénieurs alimentaires/ région chaude), Montpellier

2. FAOSTAT (2014) Mangoes gross production value (Cameroon). FAO Statistics Division. http://faostat.fao.org/site/613/DesktopDefault.aspx?\#ancor. Accessed 26 June 2014

3. Ashoush IS, Gadallah MGE (2011) Utilization of mango peels and seed kernels powders as sources of photochemicals in biscuit. World J Dairy \& Food Sciences 6(1):35-42

4. Dorta E, Gloria ML (2012) Using drying treatments to stabilize mango peel and seed: effect on antioxidant activity. LWT Food Sci Technol 45:261-268

5. Abdalla AEM, Darwish SM, Ayad EHE, El-Hamahmy RM (2007) Egyptian mango by-product 1: compositional quality of mango seed kernel. Food Chem 103:1134-1140

6. Nzikou JM, Kimbonguila A, Matos L, Loumouamou B, Pambou-Tobi NPG, Ndangui CB, Abena AA, Silou TH, Scher J, Desobry S (2010) Extraction and characteristics of seed kernel oil from mango (Mangifera indica). Res J Environmental and Earth Sci 2(1):31-35 
7. Solis-Fuentes JA, Duran-de-Bazua MC (2004) Mango seed uses: thermal behavior of mango seed almond fat and its mixtures with cocoa butter. Bioresour Technol 92:71-78

8. Abdalla AEM, Darwish SM, Ayad EHE, El-Hamahmy RM (2007) Egyptian mango by-product 2: antioxidant and antimicrobial activities of extract and oil from mango seed kernel. Food Chem 103:1141-1152

9. Arogba SS (1997) Physical, chemical and functional properties of Nigerian mango (Mangifera indica) kernel and its processed flour. J Sci Food Agric 73:321-328

10. Ebiloma UG, Arogba SS, Aminu OR (2011) Some activities of peroxydase from mango (Mangifera indica L. Var. Mapulehu) kernel. Int J Biol Chem 5:200-206

11. Fayeye TR, Joseph K (2004) Effects of dietary dehulled, sundried mango seed kernel meal on growth and carcass characteristics of fryer rabbit. J Agriculture, Res Dev 3:129-139

12. Joseph JK, Aboladji J (1997) Effect of replacing maize with graded levels of cooked Nigerian mango seed kernels (Mangifera indica) in the performance, carcass yield and meat quality of broiler chickens. Bioressource Technology 61:99-102

13. Maisuthisakul P, Harnsilawat T (2011) Characterization and stabilization of the extract from mango seed kernel in a cosmetic emulsion. Kasetsart J Nat Sci 45(3):521-529

14. Turkan A, Refik P (2007) Changes in the drying characteristics and water activity values of selected pistachio cultivars during hot air drying. J Food Process Eng 30:607-624

15. Kuitche A, Kouam J, Edoun M (2006) Modélisation du profil de température dans un séchoir construit dans l'environnement tropical. J Food Eng 76:605-610

16. Larrauri JA, Ruperez P, Saura-Calixto F (1997) Effect of drying temperature on the stability of polyphenols and antioxidant activity of red grape pomace peels. J Agric Food Chem 45(4):1390-1393

17. Podsedek A (2007) Natural antioxidants and antioxidant capacity of Brassica vegetables: a review. LWT - Food Sci Technology 40:1-11

18. Louvet F, Delplanque L (2005) Les Plans d'Expériences : une approche pragmatique et illustrée. Expérimentique Orléans, France

19. Giovanni M (1983) Response surface methodology and product optimization. J Food Technol 37:41-45

20. Ross T (1996) Indices for performance evaluation of predictive models in food microbiology. J Appl Bacteriol 81:501-508

21. Baranyi J, Pin C, Ross T (1999) Validating and comparing predictive models. Int J Food Microbiol 48:159-166

22. AFNOR (1982) Recueil des normes françaises des produits dérivés des fruits et légumes, 1st edn. Association Française de Normalisation, Paris, France

23. IUPAC (1979) Standard methods for the analysis of oils, fats and derivatives International Union of Pure and Applied Chemistry, 6th edn. Pergamon Press Ltd., Great Britain

24. Makkar HPS, Blummel M, Borowy NK, Becker K (1993) Gravimetric determination of tannins and their correlations with chemical and protein precipitation methods. J Sci Food and Agriculture 61:161-165

25. Oyaizu M (1986) Studies on products of browning reaction prepared from glucosamine. Jpn J Nutr 44:307-314

26. Reyes A, Ceron S, Zuniga R, Moyano P (2007) A comparative study of microwave-assisted air drying of potato slices. Biosys Eng 98:310-318

27. Pickles CA (2003) Drying kinetics of nickeliferous limonitic laterite ores. Miner Eng 16:1327-1338

28. Sharma GP, Prasad S (2004) Effective moisture diffusivity of garlic cloves undergoing microwave-convective drying. J Food Eng 65:609-617

29. Celma AR, Cuadros F, Lopez-Rodriguez F (2012) Convective drying characteristics of sludge from treatment plants in tomato processing industries. Food Bioprod Process 90:224-234

30. Sharma GP, Verma RC, Pathare PB (2005) Thin-layer infrared radiation drying of onion slices. J Food Eng 67:361-366

31. Tallman KA, Roschek B, Porter NA (2004) Factors influencing the autoxidation of fatty acids: effect of olefin geometry of the nonconjugated diene. J Am Chem Soc 126:9240-9247

32. Mujumdar AS (2007) Handbook of industrial drying, 3rd edn. Taylor \& Francis, UK

33. Frankel EN (1985) Chemistry of autoxidation: mechanism, products and flavor significance. In: Min DB, Smouse TH (eds) Flavor chemistry of fats and oils. AOCS Press, Champaign, IL, p 1
34. Nicoli MC, Anese M, Parpinel M (1999) Influence of processing on the antioxidant properties of fruit and vegetables. Trends Food Sci Technol 10(3):94-100

35. Sanjuán N, Benedito J, Clemente G, Mulet A (2000) The influence of pretreatments on the quality of dehydrated broccoli stems. Food Sci Technol Int 8(3):227-234

36. Que F, Mao L, Fang X, Wu T (2008) Comparison of hot air drying and freeze drying in the physicochemical properties and antioxidant activities of pumpkin (Cucurbita moschata Duch) flours. Int J Food Sci Technol 43(7):1195-1201

37. Potter NN, Hotchkiss JH (1998) Food science, 5th edn. Springer. New York

38. Erbay Z, Icier F (2009) Optimization of hot air drying of olive leaves using response surface methodology. J Food Eng 91:533-541

39. Hayat K, Zhang X, Farooq U, Abbas S, Xia S, Jia C, Zhong F, Zhang J (2010) Effect of microwave treatment on phenolic content and antioxidant activity of citrus mandarin pomace. Food Chem 123:423-429

40. Eichner K (1981) Antioxidative effect of Maillard reaction intermediates. Progr Food Nutr 5:441-451

41. Anese M, Pittia P, Nicoli MC (1993) Oxygen consuming properties of heated glucose-glycine aqueous solutions. Ital J Food Sci 5:75-79

42. Nicoli MC, Anese M, Manzocco L, Lerici CR (1997) Antioxidant properties of coffee brews in relation to the roasting degree. Lebensm-Wiss u-Technol 30:292-297

43. Nicoli MC, Anese M, Parpinel MT, Franceschi S, Lerici CR (1977) Study on loss and/or formation of antioxidants during processing and storage. Cancer Lett 114:71-74

44. Gupta MK (1993) Processing to improve soybean oil quality. Inform 4(11):1267-1272

\section{Submit your manuscript to a SpringerOpen ${ }^{\odot}$ journal and benefit from:}

- Convenient online submission

- Rigorous peer review

- Immediate publication on acceptance

- Open access: articles freely available online

- High visibility within the field

- Retaining the copyright to your article

Submit your next manuscript at $>$ springeropen.com 